Bulgarian Academy of Sciences. Space Research and Technology Institute.

Aerospace Research in Bulgaria. 31, 2019, Sofia

DOI: https://doi.org/10.3897/arb.v31.e10

\title{
DETERMINING THE BALLISTIC CHARACTERISTICS OF SPACE PENETRATOR
}

\author{
Stoyko Stoykov \\ Aviation Faculty, National Military University, Bulgaria \\ e-mail: sostoykov@nvu.bg
}

Keywords: Planet investigation, Penetrator, Modeling the movement, Aerodynamic tube.

\begin{abstract}
To model the movement of an aviation penetrator, it is necessary to know the coefficient of the drag and the coefficient of the lift force. The article presents a method of calculating them using the geometric dimensions of the penetrator. The obtained values of the coefficients are compared with those obtained when blowing a penetrator in the aerodynamic tube. By the sustainability criterion is determines the degree of damping of the penetrator. The results of modeling the movement of the penetrator show, that the mathematical model of motion can be used to solve the task of targeting.
\end{abstract}

\section{Introduction}

The mathematical modeling of a penetrator requires information on the drag coefficient and the lift force. The article offers a method of calculating them using the geometric dimensions of the penetrator.

\section{Results}

The test is conducted for a penetrator with the following characteristics:

- $\quad \Theta=21.39 \mathrm{~s}$, characteristic fall time;

- $\mathrm{m}_{\bar{\sigma}}=64 \mathrm{~kg}$, mass; $\mathrm{d}_{\sigma}=0.203 \mathrm{~m} ; \mathrm{s}_{\bar{\sigma}}=\frac{\pi \mathrm{d}_{\sigma}^{2}}{4}=0.0324 \mathrm{~m}^{2} ; \mathrm{L}_{\mathrm{K}}=0.835 \mathrm{~m} ;$

- $\quad \mathrm{H}_{\mathrm{cr}}=0.397 \mathrm{~m} ; \mathrm{H}_{\mathrm{K}}=0.40 \mathrm{~m} ; \mathrm{D}_{\mathrm{cr}}=0.205 \mathrm{~m}$.

Ballistic coefficient " $\mathrm{c}$ " is determined by form. $[3,7]$ :

$$
\mathrm{c}=(\Theta-\mathrm{a}) \frac{1}{\mathrm{~K}}=1.4649,
$$

where $\mathrm{a}, \mathrm{k}$ are coefficients $(\mathrm{a}=20.202 ; \mathrm{k}=0.811)$.

The coefficient of form $i$ is determined by form [2]: 


$$
\mathrm{i}=\frac{\mathrm{cm}_{\tilde{\sigma}}}{\mathrm{d}_{\sigma}^{2}} 10^{-3}=2.275 \text {. }
$$

For the standard drag coefficient, the Siachi law $\mathrm{C}_{\mathrm{xe}}(\mathrm{M}=0)=0.255$ [7] is used. The coefficient of resistance $\mathrm{C}_{\mathrm{xb}}$ is determined by formula [4] and for aviation penetrator it equals:

$$
\mathrm{C}_{\mathrm{x} \sigma}=0.5801 \text {. }
$$

Through the analytical formula [4]

$$
\mathrm{C}_{\mathrm{x} \tilde{\sigma}}=2\left[\mathrm{C}_{\mathrm{x} \tilde{}}^{0}+0,0052\left(\mathrm{l}_{\mathrm{K}}-1\right)+\mathrm{Ah}_{\mathrm{cт}}+\mathrm{B}_{1}\left(\mathrm{~d}_{\mathrm{cт}}-1,3\right)\right],
$$

the impedance coefficient $\mathrm{C}_{\mathrm{xba}}$ is determined.

The relative dimensions of the penetrator are:

$$
\begin{aligned}
& \mathrm{l}_{\mathrm{K}}=\frac{\mathrm{L}_{\mathrm{K}}}{\mathrm{d}_{\sigma}}=4.1133 ; \mathrm{h}_{\mathrm{cr}}=\frac{\mathrm{H}_{\mathrm{cT}}}{\mathrm{d}_{\sigma}}=1.9557 ; \mathrm{d}_{\mathrm{cT}}=\frac{\mathrm{D}_{\mathrm{cT}}}{\mathrm{d}_{\mathrm{\sigma}}}=1.0099 ; \\
& \mathrm{h}_{\mathrm{K}}=\frac{\mathrm{H}_{\mathrm{K}}}{\mathrm{d}_{\sigma}}=1.9704,
\end{aligned}
$$

The values $\mathrm{C}_{\mathrm{x} \sigma}^{0}$ and $\mathrm{A}$ are determined by $[5,7]$ and the following values are taken:

$$
\mathrm{C}_{\mathrm{x} \overline{0}}^{0}=0.053 ; \mathrm{A}=0.0646 .
$$

The coefficient $B_{1}$ is determined by form. [4]:

$$
\mathrm{B}_{1}=-0,0274 \mathrm{~h}_{\mathrm{cT}}+0,0319=-0.0209 .
$$

The front of the penetrator has a flat shape, i.e., $\mathrm{h}_{\mathrm{g}} \approx 0$, then the calculated value of $\mathrm{C}_{\mathrm{xb}}$ is increased by 0.2 [4]. Since the tailpiece of the stabilizer has feathers and two rings, calculations are made for a box stabilizer.

For the coefficient of drag impulse $\mathrm{C}_{\mathrm{xba}}$ we obtain:

$$
\mathrm{C}_{\text {хба }}=2\left[\mathrm{C}_{\text {хб }}^{0}+0,0052\left(\mathrm{l}_{\mathrm{K}}-1\right)+\mathrm{Ah}_{\text {ст }}+\mathrm{B}_{1}\left(\mathrm{~d}_{\text {ст }}-1,3\right)\right]+0,2=0,6032 .
$$

When blowing a model of a aviation penetration at $\mathrm{M}=0$ for the coefficient of impedance $\mathrm{C}_{\mathrm{xb}}$, the following result is obtained:

$$
\mathrm{C}_{\mathrm{xbo}}=0.5701 \text {. }
$$

The values of the drag coefficients $\mathrm{C}_{\mathrm{xb}}$ and $\mathrm{C}_{\mathrm{xba}}$ are close to the value of $\mathrm{C}_{\mathrm{xbo}}$ determined by blowing the model. 
This indicates that the proposed methods using the reference drag coefficient and using the geometric dimensions of the penetrator can be used to calculate the elements of the penetrator trajectory.

As a result of blowing the aviation penetrator pattern at different angles of attack, the following results for the coefficient $\mathrm{C}_{\mathrm{xb}}(\alpha)$ of drag resistance (Table 1 and Figure 1) are obtained.

Table 1. Dependency of $C_{x \bar{\sigma}}(\alpha)$

\begin{tabular}{|l|c|c|c|c|c|c|c|c|c|}
\hline $\begin{array}{l}\boldsymbol{\alpha}_{\overline{\boldsymbol{\sigma}}}, \\
\text { deg. }\end{array}$ & $\mathbf{0}$ & $\mathbf{5}$ & $\mathbf{1 0}$ & $\mathbf{1 5}$ & $\mathbf{2 0}$ & $\mathbf{2 5}$ & $\mathbf{3 0}$ & $\mathbf{3 5}$ & $\mathbf{4 0}$ \\
\hline $\mathbf{C}_{\mathbf{x} \tilde{6}}$ & 0.5701 & 0.5701 & 0.6185 & 0.7653 & 1.1172 & 1.762 & 2.7876 & 4.2819 & 6.3326 \\
\hline
\end{tabular}

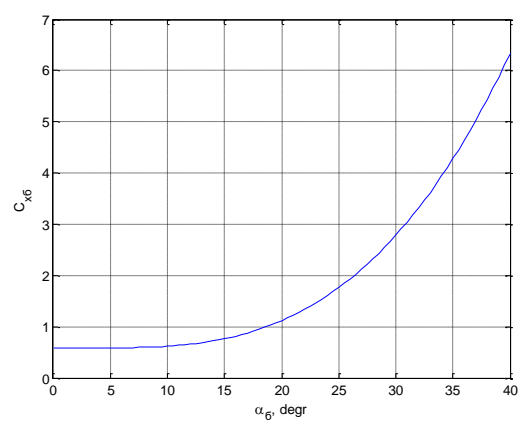

Fig. 1. Relevance of the coefficient Cxb (ab) of the impedance of the angle of attack $\alpha b$

Using the Saichi law as a reference law for the change of the resistance and the results of the Table 2, the dependence of $\mathrm{C}_{\mathrm{xb}}$ (M, a) (Fig. 2) is obtained. For the conditions under consideration it is assumed that the coefficient of the form is constant.

Table 2. Dependency of $\mathrm{C}_{\mathrm{x} \sigma}(\mathrm{M}, \alpha)$

\begin{tabular}{|l|c|c|c|c|c|c|}
\hline $\mathbf{C}_{\mathbf{x} \boldsymbol{0}}(\mathbf{M}, \boldsymbol{\alpha})$ & $\mathbf{M}=\mathbf{0}$ & $\mathbf{0 , 2}$ & $\mathbf{0 , 4}$ & $\mathbf{0 , 6}$ & $\mathbf{0 , 8}$ & $\mathbf{1}$ \\
\hline $\boldsymbol{\alpha = \mathbf { 0 } ^ { \mathbf { 0 } }}$ & 0.5701 & 0.5701 & 0.5824 & 0.5892 & 0.6484 & 1.2422 \\
\hline $\mathbf{1 0}^{\mathbf{0}}$ & 0.6185 & 0.6185 & 0.6209 & 0.6282 & 0.6913 & 1.3243 \\
\hline $\mathbf{2 0}^{\mathbf{0}}$ & 1.1172 & 1.1172 & 1.1216 & 1.1347 & 1.2486 & 2.3921 \\
\hline $\mathbf{3 0}^{\mathbf{0}}$ & 2.7876 & 2.7876 & 2.7985 & 2.8313 & 3.1156 & 5.9687 \\
\hline $\mathbf{4 0}^{\mathbf{0}}$ & 6.3326 & 6.3326 & 6.3574 & 6.4319 & 7.0776 & 13.5592 \\
\hline
\end{tabular}




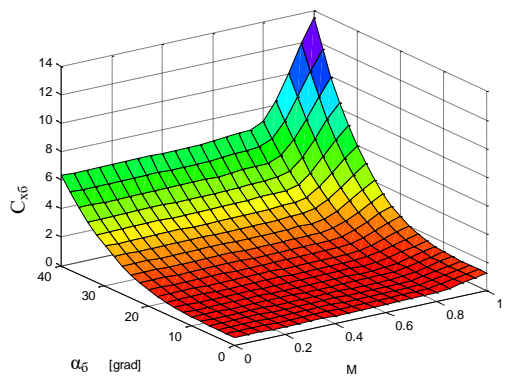

Fig. 2. Dependency of $\mathrm{C}_{\mathrm{x} \sigma}(\mathrm{M}, \alpha)$

For the coefficient Lift Force of the formula [6, 7], its values for different angles of attack were calculated (Table 3, Figure 3).

Table 3. Dependency of $C_{y \sigma}$ от $\alpha_{\sigma}$

\begin{tabular}{|c|c|c|c|c|c|c|c|c|c|}
\hline $\begin{array}{c}\boldsymbol{\alpha}_{\overline{\mathbf{\sigma}}}, \\
\mathbf{d e g}\end{array}$ & $\mathbf{0}$ & $\mathbf{5}$ & $\mathbf{1 0}$ & $\mathbf{1 5}$ & $\mathbf{2 0}$ & $\mathbf{2 5}$ & $\mathbf{3 0}$ & $\mathbf{3 5}$ & $\mathbf{4 0}$ \\
\hline $\mathbf{C}_{\mathbf{y} \boldsymbol{0}}$ & 0 & 0.4740 & 0.8958 & 1.2656 & 1.5833 & 1.8490 & 2.0625 & 2.2240 & 2.3333 \\
\hline
\end{tabular}

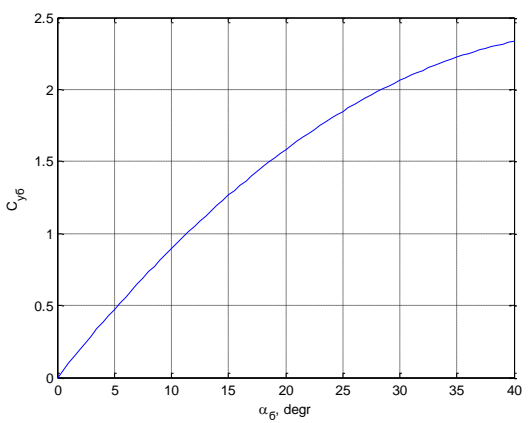

Fig. 3. Dependency of the coefficient $C_{y \sigma}$ om $\alpha_{\sigma}$

Using the sustainability criterion [4], the degree of damping of fluctuations is determined:

$$
\mathrm{K}(\mathrm{S})=0.2885,
$$

which satisfies the condition of sustainability.

As a result of the mathematical modeling of the aviation penetrator movement under different start conditions, the deceleration time of the penetrator attack angle $\alpha b$, the coefficients of: the drag resistance $C_{x b}$, the lift force $C_{y b}$ and the moment $\mathrm{m}_{\mathrm{z}}$ (Figs. 4-10). 
When solving the penetrator motion equations for conditions $\lambda=0^{\circ}$, $\mathrm{H}=500 \mathrm{~m}, \mathrm{~V}=180 \mathrm{~m} / \mathrm{s}, \alpha_{0}=4^{\circ}$ the oscillation damping time $\mathrm{t}=0.82 \mathrm{~s}$ $\left(\alpha_{b}=0.01^{\circ}\right)$, (Fig. 4). The $C_{x b}$ coefficient of the drag impedance changes insignificantly (from 0.5895 to 0.5845 ), (Fig. 5).

The coefficient of Lift $\mathrm{C}_{\mathrm{yb}}$ and the coefficient $\mathrm{m}_{\mathrm{z}}$ of the moment diminish analogously, as the angle of attack (Figs. 6,7).

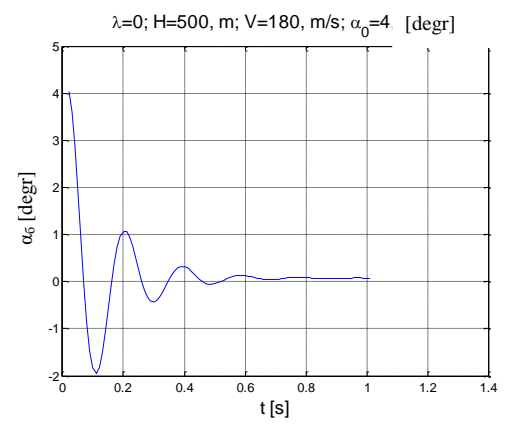

Fig. 4. Dependence of $(\alpha b)$ from time $(t)$

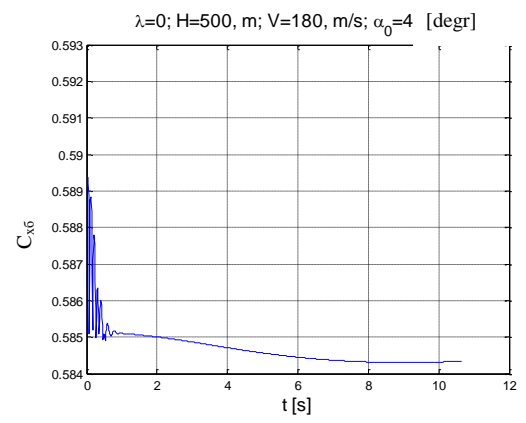

Fig. 5. Dependence of $C_{x \sigma}$ from time $(t)$

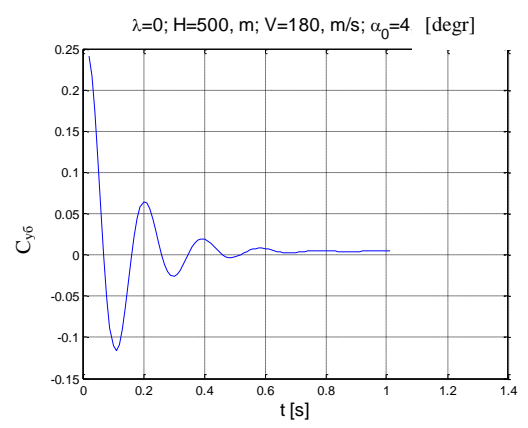

Fig. 6. Dependence of $C_{y \sigma}$ from time ( $\left.t\right)$ 


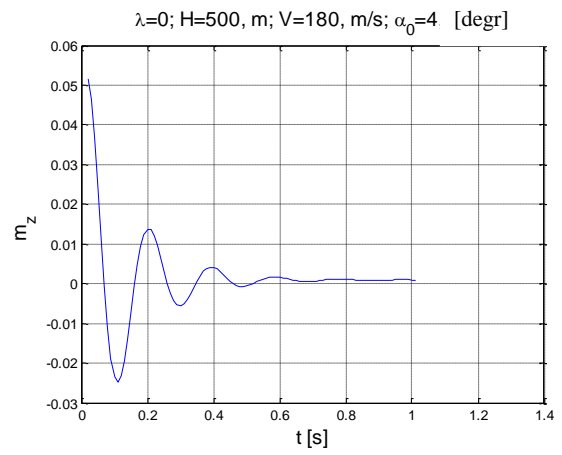

Fig. 7. Dependence of $m_{z}$ from time $(t)$

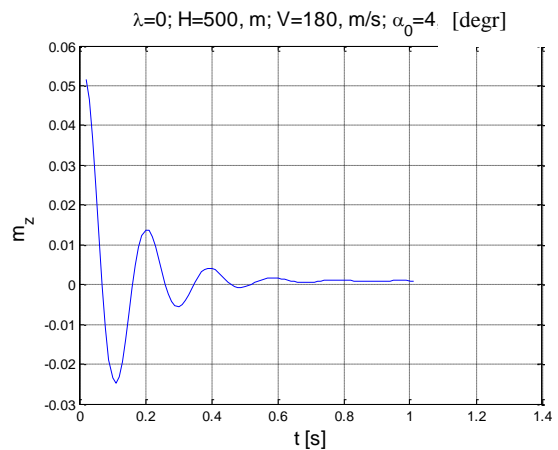

Fig. 8. Dependence of $m_{z}$ from time $(t)$
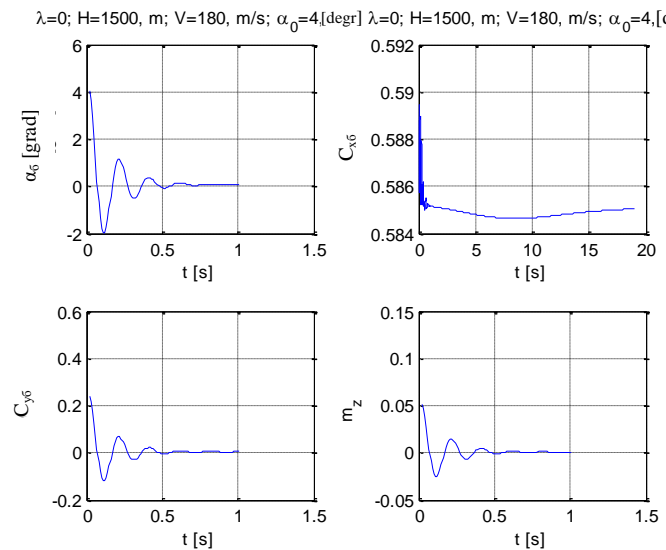

Fig. 9. Dependence of $\alpha_{\sigma}, C_{x б}, C_{y \sigma} u m_{z}$ from time ( $t$ ) 

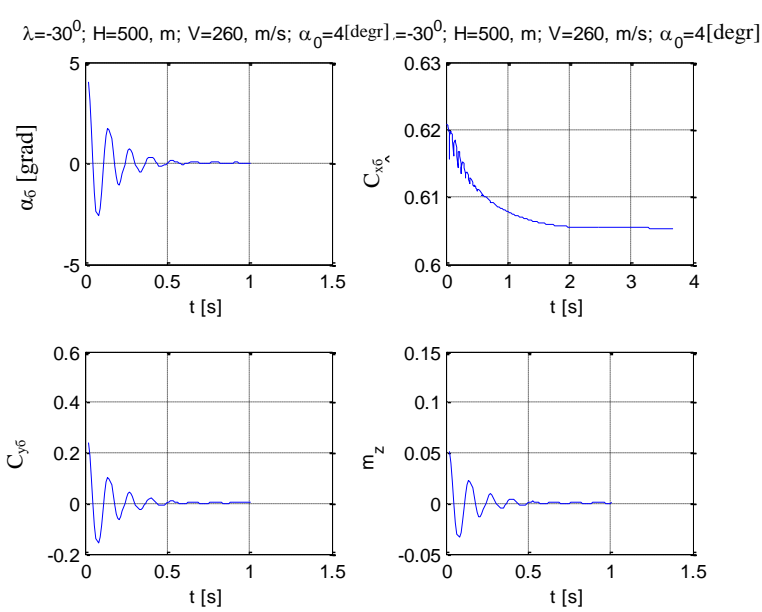

Fig. 10. Dependence of $\alpha_{\bar{\sigma}}, C_{x \bar{\sigma}}, C_{y \bar{\sigma}}$ u $m_{z}$ from time ( $t$ )

\section{Conclusions}

The results of the mathematical modeling of the movement of the aviation penetrator (shown in the above figures) lead to the following conclusions:

1. As the penetrator starts up, the damping time of $\alpha b$ decreases and the frequency of oscillations increases;

2. By increasing the initial attack angle $\alpha 0$ of the bomb, the $\mathrm{C}_{\mathrm{xb}}$ coefficient of the resistance of the penetrator changes insignificantly;

3. The character of the change of the coefficients $\mathrm{C}_{\mathrm{yb}}, \mathrm{m}_{\mathrm{z}}$ is the same as the angle of attack $\alpha_{b}$;

4. With an increase in the angle of latency $\lambda$, the decay time of ab decreases;

5. The damping time of $\alpha b$ does not depend on the height of the penetrator.

The results obtained show that the aviation penetrator pattern created can be used to solve the task of targeting.

\section{References}

1. Atanasov, M. A., V"zmozhnosti za reshavane na zadachata na pricelvane pri bombopuskane po "glova skorost, Dolna Mitropolija, PhD thesis, NVU „Vasil Levski", 2006. (in Bulgarian)

2. Atanasov, M. A., Tochnost na strelbata i bombopuskaneto s izpolzvane na aviacionen pricelen kompleks s"s sledjashta sistema, NVU „Vasil Levski”, 2018. (in Bulgarian)

3. Baranov, V. and G. Mardirosjan. Svjazannaja zadacha optimizacii parametrov penetratorov dlJa mezhplanetnыh issledovanij. Sb. nauchnыh trudov Tulyskogo gosud. universiteta, Tula, 1996, pp. 35-39. (in Russian) 
4. Pokrovskij, G. I. Sassaparely V. I. et al., Kurs aviacionnыh bomb, M., VVIA „N. E. Zhukovskogo“, 1950. (in Russian)

5. Mardirosjan, G., D. Jordanov, L. Kraleva, and D. Danov. Penetrator za ekologichni izsledvanija. In: Proceedings. "30 godini organizirani kosmicheski izsledvanija v B"lgarija", SRI-BAS, Sofia, 1999, pp. 385-389. (in Bulgarian)

6. Mardirossian, G., D. Danov. Preliminary analysis or the ballistic parameters of a penetrator for ecological studies. Aerospace Res. in Bulgaria, 2001, 16, pp. 89-96.

7. Stojkov, O. S., Metodi i tochnost na reshavane na zadachata na pricelvane pri bombopuskane, Dolna Mitropolija, 2010, ISBN 978-954-713-100-2. (in Bulgarian)

\section{РЕЗУЛТАТИ ОТ МОДЕЛИРАНЕ НА ДВИЖЕНИЕТО НА КОСМИЧЕСКИ ПЕНЕТРАТОР}

\section{С. Стойков}

\section{Резюме}

За моделиране на движението на космически пенетратор е необходимо да се знае коефициента на челно съпротивление и коефициента на подемната сила. В статията се предлага метод за тяхното изчисляване чрез геометричните размери на пенетратора. Получените стойности на коефициентите се сравняват с тези получени при обтичане на модела на пенетратора в аеродинамична тръба. Чрез критерия за устойчивост е определена степента на затихване на колебанията на пенетратора. Получените резултати от моделиране на движението на пенетратора показват, че математическият модел за движение може да се използва за решаване на задачата на прицелване. 